\title{
EFEKTIFITAS METODE PEMBELAJARAN FOCUS GROUP DISCUSSION (FGD) DALAM MENINGKATKAN PRESTASI BELAJAR PADAMATERI KEPERAWATAN JIWA PADA MAHASISWA JURUSAN KEPERAWATAN POLTEKES KEMENKES MATARAM TAHUN 2018
}

\author{
Eka Rudy Purwana ${ }^{1}$, Masadah ${ }^{2}$ \\ ${ }^{1,2}$ Jurusan Keperawatan, Poltekkes Kemenkes Mataram, Indonesia
}

\begin{abstract}
Abstrak
Materi Keperawatan Jiwa dianggap sulit karena harus menghadapi pasien dengan gangguan jiwa. Pada beberapa mahasiswa lain mengungkapkan bahwa metode pengajaran yang dilakukan oleh dosen kurang efektif karena lebih mengedepankan metode ceramah yang cenderung mengedepankan hapalan bersifat teoritis, sedangkan disisi lain mahasiswa sangat jarang berdiskusi tentang isi materi yang diajarkan. Mencermati hasil dan analisis observasi yang dilakukan, peneliti mengambil sebuah tawaran solusi yakni pembelajaran dengan menggunakan metode Focus Group Discussion (FGD) yang merupakan salah satu strategi untuk mengumpulkan data yang melibatkan interaksi sosial diantara para individu dalam suatu diskusi berseri. Metode ini terbukti banyak digunakan untuk pengumpulan data. Penelitian ini adalah kuantitatif dengan desain penelitian Pre-Experimental Design One-Group Pre test-Post test Design. Populasi adalah semua mahasiswa Tingkat 2 Semester 3 Jurusan Keperawatan Prodi D.III dan D.IV Keperawatan Mataram, sedangkan sampel menggunakan 160 responden yang memenuhi kriteria inklusi. Uji statistik yang digunakan adalah Wilcoxon. Hasil menunjukan bahwa perbedaan pengetahuan pre dan post test kelompok perlakuan sebesar $\mathrm{p}=0,00$, nilai $\mathrm{p}<0,05$ yang berarti ada perbedaan signifikansi antara pengetahuan pre test dan post test pada kelompok perlakuan.
\end{abstract}

Kata Kunci: Pengetahuan, Focus Group Discussion (FGD)

\section{THE EFFECTIVENESS OF THE FOCUS GROUP DISCUSSION (FGD) LEARNING METHOD IN IMPROVING LEARNING ACHIEVEMENTS IN NURSING ACADEMY OF MATARAM HEALTH POLYTHECNIC IN 2018}

\begin{abstract}
Mental health nursing lessons is considered difficult because it has to deal with patients with mental disorders, in some other students revealed that the teaching methods carried out by lecturers were less effective because they prioritized lecture methods that tended to prioritize theoretical memorization, on the other hand students rarely discussed the contents of the material taught. Looking at the results and analysis of observations made, the researcher took a solution offer, namely learning using the Focus Group discussion method. is one strategy to collect data that involves social interaction among individuals in a series of discussions. This method proved to be widely used for data collection. This research is quantitative with a Pre-Experimental design One-Group Pretest-Posttest Design research design. The population is all level 2 students of semester 3 majoring in Nursing Study Program D.IV and DIII mataram heath polytechnic, while the sample uses 160 respondents who meet the inclusion criteria. The statistical test used is Wilcoxon. The results showed that the difference in knowledge of the pre and post test of the treatment group was $P=0.00$, the $P$ value was $<0.005$, which meant that there was a significant difference between the pre test and post test knowledge in the treatment group.
\end{abstract}

Keywords: Knowledge, Focus Group Discussion (FGD) 


\section{PENDAHULUAN}

Dalam dunia pendidikan sering kali muncul masalah yang berhubungan dengan proses pembelajaran yaitu lemahnya proses pembelajaran. Dalam proses pembelajaran, seorang pengajar memiliki peranan penting demi tercapainya kegiatan pembelajaran. Dari hasil survey pendahuluan yang dilakukan peneliti pada Tingkat 2 Semester 4 Prodi D.III dan D.IV Keperawatan Mataram menunjukkan beberapa mahasiswa mengungkapkan bahwa materi Keperawatan Jiwa dianggap sulit karena harus menghadapi pasien dengan gangguan jiwa. Pada beberapa mahasiswa lain mengungkapkan bahwa metode pengajaran yang dilakukan oleh dosen kurang efektif karena lebih mengedepankan metode ceramah yang cenderung mengedepankan hafalan bersifat teoritis, sedangkan disisi lain mahasiswa sangat jarang berdiskusi tentang isi materi yang diajarkan. Mencermati hasil dan analisis observasi yang dilakukan, peneliti mengambil sebuah tawaran solusi yakni metode Focus Group Discussion (FGD), sebuah model pembelajaran kooperatif berorientasi pada keaktifan belajar mahasiswa yang diharapkan mampu memberikan dukungan untuk mengatasi permasalahan ini. FGD merupakan salah satu strategi untuk mengumpulkan data yang melibatkan interaksi sosial diantara para individu dalam suatu diskusi berseri. Metode ini terbukti banyak digunakan untuk pengumpulan data. Saat ini, metode FGD banyak digunakan para manajer perawat dalam melakukan evaluasi berbagai program pendidikan untuk para pasien (Leung et al., 2005), untuk itu peneliti tertarik untuk memodifikasi dengan pemecahan masalah pada soal ujian kompetensi mahasiswa Keperawatan, sehingga diharapkan mahasiswa mampu menyelesaikan soal ujian kompetensi perawat yang sekarang ini dijadikan sebagai suatu keharusan bagi lulusan Sarjana Keperawatan di tahun 2018.

\section{METODE}

Dalam penelitian ini rancangan penelitian yang digunakan adalah metode input proses output. Jenis penelitian yang digunakan dalam penelitian ini adalah penelitian eksperimen (experimental research), yaitu penelitian yang diartikan sebagai pendekatan kuantitatif penuh artinya memenuhi semua persyaratan yang menguji sebab dan akibat. Pada penelitian ini menggunakan quasi eksperimental yaitu adanya 2 kelas yang terdiri dari kelompok kontrol dan kelompok perlakuan/eksperimen. Pada 2 kelas atau kelompok ini sampel dipilih secara random kemudian dilakukan pre test dan post test pada penerapan pembelajaran dikelas. Populasi dan sampel untuk menguji hipotesa dilakukan dengan SPSS 16,0 For Windows melalui metode statistic Wilcoxon karena pada pengujian normalitas data, data tersebut terdistribusi tidak normal.

Populasi pada penelitian ini adalah seluruh mahasiswa Tingkat 2 Semester 4 Program Studi D.III dan D.IV Keperawatan Mataram. Sampel penelitian ini menggunakan total sampling, yakni keseluruhan responden adalah seluruh mahasiswa Keperawatan Tingkat 2 Semester 4 Program Studi D.III dan D.IV Keperawatan Mataram Jurusan Keperawatan Politeknik Kesehatan Kemenkes Mataram. Data penelitian dianalsisis dengan menggunakan Uji Wilcoxon dengan bantuan SPSS For 
Window Release 16 dengan penentuan taraf signifikansi jika $\mathrm{p}$ value $<\alpha(0,05)$ maka $\mathrm{H}_{0}$ ditolak, jika $\mathrm{p}$ value $>\alpha(0,05)$ maka $\mathrm{H}_{0}$ diterima.

\section{HASIL PENELITIAN}

Penelitian ini dilaksanakan selama 6 bulan yaitu mulai tanggal 2 Juni sampai akhir November melalui proses pelaksanaan penelitian pasca persetujuan proposal sampai dengan proses pengolahan hasil penelitian. Tempat penelitian berada di ruang kelas Prodi D.III dan Prodi D.IV Keperawatan Mataram di jalan Kesehatan V/10 Mataram. Responden adalah mahasiswa Tingkat 2 Semester 4 yang belum pernah mendapatkan materi Keperawatan Jiwa terdiri atas kelas prodi D.III dan D.IV Keperawatan Mataram dengan total responden sejumlah 160 orang dengan rincian Tingkat 2 Semester 4 Prodi D.III Keperawatan Mataram berjumlah 72 orang yang mengikuti penelitian dan mahasiswa Tingkat 2 Semester 4 Prodi D.IV Keperawatan Mataram berjumlah 88 orang.

Berdasarkan tingkat pengetahuan menunjukan bahwa sebagian besar responden berada pada kelompok umur $>21$ tahun, yaitu sebanyak 108 orang (67\%), sedangkan kelompok umur $\leq 20$ tahun sebanyak 52 orang (33\%).

Dari data jenis kelamin menunjukan bahwa, sebanyak 46 orang (29\%) berjenis kelamin lakilaki, dan 114 orang $(71 \%)$ berjenis kelamin perempuan.

Dari hasil tabulasi silang penelitian menunjukkan bahwa nilai pre test dan post test dari kelompok perlakuan/ekperimen menunjukkkan hubungan yang signifikan dengan nilai $\mathrm{p}<0,05$ yaitu nilai $\mathrm{p}=0,00$, sedangkan untuk hasil tabulasi silang penelitian pre test dan post test dari kelompok kontrol menunjukkkan hubungan yang signifikan dengan nilai $\mathrm{p}<0,05$ yaitu nilai $\mathrm{p}=0,00$.

Dari hasil tabulasi silang penelitian nilai pre test kelompok perlakuan/eksperimen dan pre test dari kelompok kontrol menunjukkkan adanya hubungan yang signifikan, dengan nilai $\mathrm{p}<0,05$ yaitu nilai $\mathrm{p}=0,00$, sedangkan untuk hasil tabulasi silang nilai post test kelompok perlakuan/eksperimen dan post test dari kelompok kontrol menunjukkan hubungan yang signifikan, dengan nilai $\mathrm{p}<0,05$ yaitu nilai $\mathrm{p}=0,01$.

Setelah dilakukan uji analisa data dan menguji hasil penelitian dengan menggunakan uji statistik Wilcoxon diperoleh hasil yang memerlukan pembahasan tentang metode Perlakuan pada Mahasiswa Jurusan Keperawatan Poltekes Mataram.

Berdasarkan uji statistik Wilcoxon, ada perbedaan yang signifikan pada nilai yang didapat dari responden pada kelompok perlakuan/eksperimen dengan nilai $\mathrm{p}<0,05$ yaitu $\mathrm{p}=0,00$ jika dibandingkan dengan kelompok kontrol dengan nilai $p<0,05$ yaitu $p=0,01$.

Dari hasil wawancara mendalam pada saat selesai pelaksanaan penelitian serta hasil observasi saat pelaksanaan pengambilan data, beberapa responden mengungkapkan bahwa berdiskusi dengan metode FGD lebih efektif dibandingkan bertanya dengan dosen dikarenakan terkadang tidak cukup waktu pada saat pelajaran berlangsung atau tidak percaya diri pada saat ceramah di dalam kelas dibandingkan dengan mendengarkan ceramah atau mencari literatur buku apalagi jika langsung ada 
rangsang untuk menjawab pertanyaan. Walaupun rata-rata nilai yang dicapai tidak lebih tinggi dibandingkan dengan yang mendapatkan metode pembelajaran klasikal yaitu ceramah dan tanya jawab dengan hasil pengetahuan responden pada kelompok perlakuan dengan kriteria baik dari sesi pre test berjumlah 7 orang $(8,8 \%)$ meningkat menjadi 16 orang (20\%) pada post test, kriteria cukup pada hasil pengetahuan pre test berjumlah 14 orang $(17,5 \%)$ meningkat menjadi 22 orang (27,5\%), sedangkan pada kelompok kontrol dengan kriteria baik dari sesi pre test berjumlah 20 orang (25\%) meningkat menjadi 29 orang (36\%) pada post test, kriteria cukup pada hasil pengetahuan pre test berjumlah 26 orang (32\%) menurun menjadi 25 orang (31\%).

\section{PEMBAHASAN}

Setelah dilakukan uji analisa data dan menguji hasil penelitian dengan menggunakan uji statistic Wilcoxon diperoleh hasil yang memerlukan pembahasan tentang metode Perlakuan pada Mahasiswa Jurusan Keperawatan Poltekes Mataram.

Berdasarkan uji statistic Wilcoxon ada perbedaan yang signifikan pada nilai yang diperoleh oleh responden pada kelompok Perlakuan dengan nilai $\mathrm{p}<0,05$ yaitu $\mathrm{p}=0,00$ sama jika dibandingkan dengan kelompok kontrol dengan nilai $\mathrm{p}<0,05$ yaitu $\mathrm{p}=0,00$.

Dari hasil wawancara mendalam saat selesai pelaksanaan penelitian serta hasil observasi saat pelaksanaan pengambilan data, beberapa responden mengungkapkan bahwa berdiskusi dengan metode FGD efektif dibandingkan dengan bertanya dengan dosen dikarenakan terkadang tidak cukup waktu pada saat pelajaran berlangsung atau tidak percaya diri pada saat ceramah didalam kelas dibandingkan dengan mendengarkan ceramah atau mencari literatur buku apalagi jika langsung ada rangsang untuk menjawab pertanyaan. Walaupun rata-rata nilai yang dicapai tidak lebih tinggi dibandingkan dengan yang mendapatkan metode pembelajaran klasikal yaitu ceramah dan tanya jawab yaitu hasil pengetahuan responden pada kelompok perlakuan dengan kriteria baik dari sesi pre test berjumlah 7 orang $(8,8 \%)$ meningkat menjadi 16 orang (20\%) pada post test demikian juga dengan kriteria cukup, pada hasil pengetahuan pre test berjumlah 14 orang (17,5\%) meningkat menjadi 22 orang $(27,5 \%)$, sedangkan pada kelompok kontrol dengan kriteria baik dari sesi pre test berjumlah 20 orang (25\%) meningkat menjadi 29 orang (36\%) pada post test, demikian juga dengan kriteria cukup, pada hasil pengetahuan pre test berjumlah 26 orang (32\%) menurun menjadi 25 orang (31\%). Dari hasil pertanyaan mendalam dan hasil observasi peneliti saat mahasiswa berdiskusi dengan temannya, hasil yang tidak terlalu tinggi ini kemungkinan disebabkan kemampuan tiap enumerator memfasilitasi diskusi ternyata juga ada perbedaan kemampuan dalam mengarahkan pertanyaan tersebut dan ada 1 enumerator yang pada saat diberikan pembekalan dianggap sangat mampu menjelaskan pertanyaan kuesioner tersebut tetapi kurang jelas pada saat ia menjelaskan dan membawa materi diskusi kepada respondennya, ataupun tidak adanya kontek ceramah dalam menjelaskan materi pembelajaran, sehingga nilai kelompok kontrol dapat dikatakan lebih rendah dari nilai kelompok ekperimen. Hasil penelitian ini sesuai dengan penelitian sebelumnya yang dilakukan Fardiah, proses FGD dapat 
memberikan peluang kepada responden untuk menunjukkan eksistensinya menggali potensi dari masalah yang ada sehingga dapat memecahkan masalah secara bersama-sama (2017). Hal ini juga sesuai dengan penelitian yang dilaksanakan Alfiyanti, FGD adalah suatu perolehan informasi/data yang kaya akan berbagai pengalaman sosial dari interaksi para individu yang berada dalam suatu kelompok diskusi dengan tujuan untuk mendorong peserta mengekspresikan pendapatnya secara bebas untuk memecahkan suatu masalah (Afiyanti, 2008 \& Irwanto, 2006). Penelitian dari Octavia (2015), menunjukan bahwa penelitian dengan menggunakan FGD efeketif, karena terjadi peningkatan pengetahuan setelah diberikan edukasi pada pasien dengan TB Paru.

Hasil penelitian menunjukkan bahwa hasil pengetahuan responden pada kelompok perlakuan dengan kriteria baik dari sesi pre test berjumlah 7 orang (8,8\%) meningkat menjadi 16 orang (20\%) pada post test, untuk kriteria cukup, pada hasil pengetahuan pre test berjumlah 14 orang $(17,5 \%)$ meningkat menjadi 22 orang (27,5\%), sedangkan pada kelompok kontrol dengan kriteria baik dari sesi pre test berjumlah 20 orang (25\%) meningkat menjadi 29 orang (36\%) pada post test, untuk kriteria cukup, pada hasil pengetahuan pre test berjumlah 26 orang (32\%) menurun menjadi 25 orang (31\%).

\section{KESIMPULAN}

Hasil pengetahuan responden pada kelompok perlakuan dengan kriteria baik pada sesi pre test berjumlah 7 orang $(8,8 \%)$ meningkat menjadi 16 orang (20\%) pada post test, kriteria cukup pada pre test berjumlah 14 orang (17,5\%) meningkat menjadi 22 orang $(27,5 \%)$ pada post test. Untuk hasil pengetahuan responden pada kelompok kontrol dengan kriteria baik pada sesi pre test berjumlah 20 orang (25\%) meningkat menjadi 29 orang (36\%) pada post test, kriteria cukup pada pre test berjumlah 26 orang (32\%) menurun menjadi 25 orang (31\%) pada post test.

Hasil uji statistik perbedaan pengetahuan pre dan post test kelompok perlakuan sebesar $\mathrm{p}=$ 0,00 , nilai $\mathrm{p}<0,05$ yang berarti ada perbedaan signifikansi antara pengetahuan pre test dan post test pada kelompok perlakuan, untuk kelompok kontrol hasil uji statistik perbedaan pengetahuan pre dan post test nya sebesar $\mathrm{p}=0,00$, nilai $\mathrm{p}<0,05$ yang berarti ada perbedaan signifikansi antara pengetahuan pre test dan post test pada kelompok kontrol. 


\section{DAFTAR PUSTAKA}

Afiyanti, Y. 2008. Validitas dan Reliabilitas dalam Penelitian Kualitatif. Jurnal PenelitianVol.1 Diakses pada 10 November 2017.

Aljoudi, A., Taha, A. 2009. Knowledge of Diabetes Risk Factors and Preventive Measures Among Attendees of A Primary Care Center Ineastern Saudi Arabia. Jurnal Epidemiologi. Diakses pada 10 November 2017.

Fardiah Dede. 2012. FGD Dalam Pembangunan Partisipatif. Diakses dari e Jurnal IPI Bogor.

Focus Group Process. Diakses dari: HTTP://www.isixsigma.com/pages/process.htm. Sitasi tanggal 2 Maret 2018.

Focus Group Discussion (FGD). Diakses dari HTTP://www.enolsatoe.org/contentview/15/33/. Sitasi 23 Maret 2018.

Notoatmodjo. 2012. Metodologi Penelitian Kesehatan. Jakarta. PT Rineka Citra.

Paramita, Astridia. 2013. Teknik Focus Group Discussion Dalam Penelitian Kualitatif (Focus Group Discussion Tehnique In Qualitative Research) Bulletin Penelitian Kesehatan, Vol 12. Diakses 16 April 2012.

Supit, Julita. 2018. Efektifitas Metode Edukasi Penggunaan Video dan FGD Dalam Meningkatkan Pengetahuan Pasien DM di klinik Diabetes Kimia Farma Husada Manad.e-Journal Keperawatan (e-Kep), Volume 6 Nomor 1. Diakses Mei 2018.

Syaiful, Sagala, H. DR. M.Pd. 2013. Konsep dan Makna Pembelajaran. Bandung. Penerbit ALFABETA.

Udin S. Winataputra. Wina Senjaya. 2008. Strategi Pembelajaran; Berorientasi Standar Proses Pendidikan. Jakarta. Kencana Prenada Media G. 